\title{
FACTORS AFFECTING THE LOW UTILIZATION OF DENTAL POLYCLINIC IN KARANGANYAR II COMMUNITY HEALTH CENTER ON DEMAK
}

\author{
Pamunarsih $^{\bowtie 1}$, Bedjo Santoso ${ }^{2}$, Sukini $^{3}$
}

\begin{abstract}
ABSTRAK
Salah satu upaya untuk mempertahankan gigi adalah dengan memelihara kesehatan gigi, memeriksakan gigi melalui fasilitas pelayanan kesehatan. Tingkat prevalensi karies yang tinggi tidak diimbangi dengan pemanfaatan fasilitas kesehatan gigi yang ada. Rata-rata kunjungan poliklinik gigi perbulan adalah 75 orang, hal ini tergolong rendah kurang dari $4 \%$ dari jumlah penduduk di wilayah Puskesmas Karanganyar II yaitu sebesar 146 orang. Tujuan penelitian ini ingin mengetahui faktor-faktor yang mempengaruhi rendahnya pemanfaatan Poliklinik gigi Puskesmas Karanganyar II Kabupaten Demak.

Jenis penelitian analitik menggunakan metode cross sectional. Responden adalah pasien yang datang ke Poliklinik gigi Puskesmas Karanganyar II Kabupaten Demak pada tahun 2017 sebesar 96 pasien yang diambil dengan teknik accidental sampling. Alat pengumpul data adalah kuesioner, sedangkan analisa data sendiri dilakukan dengan cara univariat dan bivariat, untuk menjawab hipotesis digunakan uji Chi Square.

Ada pengaruh tingkat pengetahuan dengan pemanfaatan poliklinik gigi di Puskesmas Karanganyar II Demak ( $p$ value $=0,000$ ). Ada pengaruh sikap responden dengan pemanfaatan poliklinik gigi di Puskesmas Karanganyar II Demak ( $p$ value $=0,000$ ). Tidak ada pengaruh sarana prasarana dengan pemanfaatan poliklinik gigi di Puskesmas Karanganyar II Demak ( $p$ value =0,107). Ada pengaruh sikap petugas kesehatan dengan pemanfaatan poliklinik gigi di Puskesmas Karanganyar II Demak ( $p$ value =0,000). Ada pengaruh tingkat pengetahuan, sikap responden, sarana prasarana, dan sikap petugas kesehatan terhadap rendahnya pemanfaatan poliklinik gigi di Puskesmas Karanganyar II Demak.
\end{abstract}

Kata kunci : Pemanfaatan, Poliklinik gigi, Puskesmas

\begin{abstract}
One of the efforts to maintain the teeth is by maintaining dental health, routine control of dental or dental checkup through healthcare facilities. High caries prevalence rates are not matched by utilization of existing dental facilities. The average daily visit of dental polyclinic is 75 people, it is considered less than $4 \%$ of the population in Health center of Karanganyar II, which is 146 people. The purpose of this study is to find out the factors that influence the low utilization of dental poly of the Karanganyar II Health Center in Demak Regency.

Analytic research type using the cross-sectional method. Respondents were patients who came to Dental Poly Karanganyar II Demak in 2017 of 96 patients taken by accidental sampling technique. Data collection tool is a questionnaire, while analysis of the data itself is done by univariate and bivariate, to answer the hypothesis used Chi-Square test.

There is an influence of knowledge level with the utilization of dental poly in Health center of Karanganyar II Demak ( $p$-value =0,000). There is an influence of respondent attitude with the utilization of dental poly in Health center of Karanganyar II Demak ( $p$-value $=0,000)$. There is no effect of infrastructure on the utilization of dental poly in Health center of Karanganyar II Demak ( -value $=0,107)$. There is an influence of health officer attitude with a utilization of dental poly in Health center of Karanganyar II Demak ( $p$-value = 0,000). There is an influence of knowledge level, respondent attitude, means of infrastructure, and attitude of health officer to low utilization of dental poly in Health center of Karanganyar II Demak.
\end{abstract}

Keywords : Utilization, Dental Poly, Health center

1) Perawat gigi Puskesmas Karanganyar II Kabupaten Demak

2,3) Dosen Jurusan Keperawatan gigi Poltekkes Kemenkes Semarang

: bokkaranganyar02@gmail.com 


\section{PENDAHULUAN}

Pembangunan kesehatan bertujuan untuk meningkatkan kesadaran, kemauan dan kemampuan hidup sehat bagi setiap orang agar terwujud derajat kesehatan masyarakat yang optimal, meliputi kesehatan fisik, mental dan sosial. Kesehatan gigi dan mulut merupakan bagian integral dari kesehatan umum, artinya seseorang yang sakit gigi akan terganggu kesehatannya secara umum (Kementrian kesehatan RI, 2012).

Berdasarkan riset Kesehatan Dasar (RISKESDAS) tahun 2013 ditemukan bahwa prevalensi karies aktif sebesar 53,2\% terjadi peningkatan yang cukup signifikan jika dibandingkan dengan tahun 2007 yang hanya sebesar 43,4\%. Di Indonesia terdapat 93.998.727 jiwa yang menderita karies dengan indeks DMF-T nasional sebesar 4,6 terdiri dari $\mathrm{D}-\mathrm{T}=1,6 ; \mathrm{M}-\mathrm{T}=2,9 ; \mathrm{F}-\mathrm{T}=0,08$ yang berarti kerusakan gigi penduduk Indonesia 460 buah gigi per 100 orang. Indikator M-T (kehilangan gigi) lebih tinggi dari pada indicator F-T (penambalan). Tingginya angka kehilangan gigi disebabkan oleh kurangnya kesedaran masyarakat tentang pentingnya mempertahankan gigi (Kementrian Kesehatan RI, 2013).

Salah satu upaya untuk mempertahankan gigi adalah dengan memelihara kesehatan gigi, kontrol secara rutin di poliklinik gigi atau memeriksakan gigi melalui fasilitas pelayanan kesehatan. Strategi pelayanan kesehatan gigi adalah meningkatkan upaya promotif dan preventif pelayanan kesehatan gigi dan mulut dengan mendorong kemandirian masyarakat, meningkatkan aksesibilitas terhadap pelayanan kesehatan gigi dan mulut yang berkualitas, meningkatkan kualitas pelayanan kesehatan gigi dan mulut, meningkatkan peran serta pemangku kepentingan/stakeholders terkait pelayanan kesehatan gigi dan mulut (Sakti, 2016).

Menurut (Peraturan Pemerintah) PP No.47 tahun 2016 tentang Fasilitas Pelayanan Kesehatan didirikan untuk menyelenggarakan pelayanan kesehatan baik promotif, preventif, kuratif, maupun rehabilitatif. Jenis dan Tingkatan Fasilitas Pelayanan Kesehatan berupa pelayanan kesehatan perseorangan, pelayanan kesehatan masyarakat. Jenis Fasilitas Pelayanan Kesehatan yaitu antara lain tempat praktik mandiri tenaga kesehatan, pusat kesehatan masyarakat, klinik, rumah sakit, apotek, unit transfusi darah, laboratorium kesehatan, optikal. Fasilitas pelayanan kesehatan memiliki tingkatan pelayanan yang terdiri atas fasilitas pelayanan kesehatan tingkat pertama (memberikan pelayanan kesehatan dasar), fasilitas pelayanan kesehatan tingkat kedua (memberikan pelayanan kesehatan spesialistik), dan fasilitas pelayanan kesehatan tingkat ketiga (memberikan pelayanan kesehatan subspesialistik).

Pemanfaatan pelayanan puskesmas adalah penggunaan pelayanan yang telah diterima pada tempat atau pemberi pelayanan kesehatan. Pemanfaatan pelayanan kesehatan paling erat hubungannya dengan kapan seseorang memerlukan pelayanan kesehatan dan seberapa jauh efektifitas pelayanan tersebut. Pada umumya seseorang akan memerlukan pelayanan kesehatan bila merasa sakit atau adanya gangguan pada kesehatannya (Brotosaputro, 2012).

Pemanfaatan pelayanan kesehatan tiap individu mempunyai kecenderungan untuk menggunakan pelayanan kesehatan yang berbeda-beda. Perbedaan ini timbul karena dipengaruhi oleh perilaku kesehatan yang menurut Green (1980) ditentukan oleh 3 faktor yaitu : faktor predisposisi (predisposing factor) yang terdiri dari pengetahuan, sikap, keyakinan, nilai, tingkah laku, dan sosial ekonomi yang mendasari perubahan perilaku; faktor pendukung (enabling factor) terwujud dalam lingkungan fisik yang meliputi tersedia atau tidaknya fasilitas/sarana kesehatan, misalnya : puskesmas, obat-obatan dan lain sebagainya; faktor pendorong (reinforcing factor) yang terwujud dalam sikap dan perilaku petugas kesehatan atau petugas lainnya, keluarga, 
guru, teman, dan sebagainya yang merupakan kelompok referensi dari perilaku masyarakat (Notoadmodjo, 2012).

Berdasarkan data penyakit gigi dan mulut di Kabupaten Demak tahun 2016, kunjungan rawat jalan gigi di seluruh Puskesmas di wilayah Kabupaten Demak untuk penyakit jaringan penyangga gigi dan jaringan periodontal 34,5\%, gangguan pertumbuhan gigi dan erupsi $21,7 \%$, karies gigi $23,2 \%$, penyakit pulpa dan jaringan periapikal 14,3\%, kelainan dentofasial termasuk mal-oklusi $0,9 \%$, calculus dan deposit lain 5\%, konsultasi dan tidak ada keluhan 2,6\% dan impaksi 1,9\%. Dengan tingkat prevalensi karies yang tinggi tidak diimbangi dengan pemanfaatan fasilitas kesehatan gigi yang ada. Hal ini dapat dilihat dari jumlah kunjungan pasien poliklinik gigi di Puskesmas Karanganyar II dengan jumlah penduduk 40.003 jiwa, capaian kunjungan pelayanan gigi pada Triwulan 1 sejumlah $2.06 \%$, Triwulan 2 sejumlah $2.13 \%$, Triwulan 3 sejumlah 2,84\%. Rata-rata kunjungan poliklinik gigi perbulan adalah 75 orang, hal ini tergolong rendah kurang dari 4\% dari jumlah penduduk di wilayah Puskesmas Karanganyar II yaitu sebesar 146 orang.

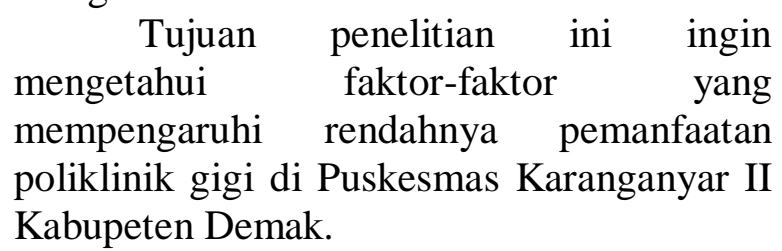

\section{METODE PENELITIAN}

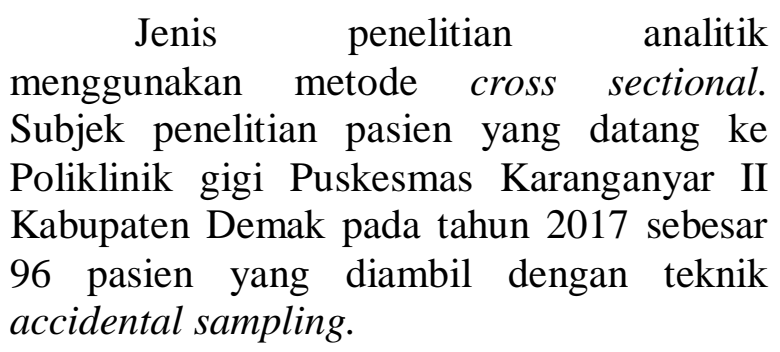

\section{HASIL DAN PEMBAHASAN}

Berikut ini disajikan hasil penelitian yang dilaksanakan sepanjang bulan FebruariMaret 2018 di poliklinik gigi Puskesmas Karanganyar II Demak :

1. Hasil Analisa Univariat

a. Tingkat Pengetahuan

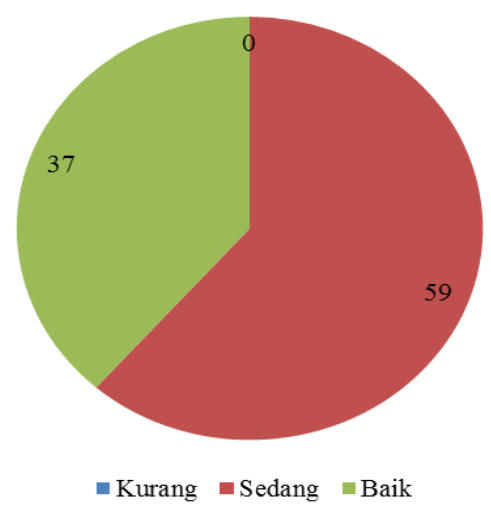

Gambar 1. Distribusi Frekuensi Responden Berdasarkan Tingkat Pengetahuan di Puskesmas Karanganyar II Demak $2018(n=96)$

Berdasarkan Gambar 1 menunjukkan sebagian besar responden memiliki tingkat pengetahuan sedang $(61,5 \%)$ dan sebagian lagi memiliki tingkat pengetahuan baik $(38,5 \%)$.

b. Sikap responden

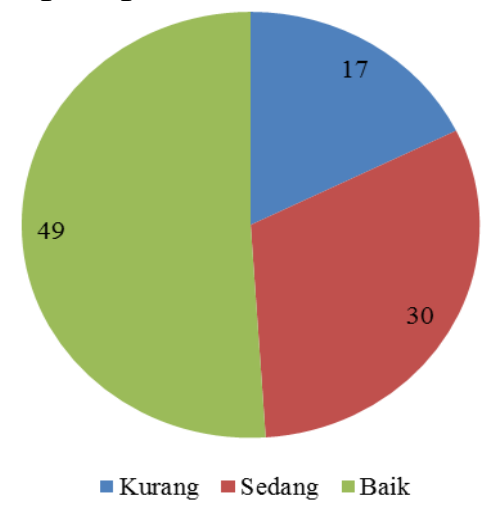

Gambar 2. Distribusi Frekuensi Responden Berdasarkan Sikap Responden di Puskesmas Karanganyar II Demak $2018(\mathrm{n}=96)$ 
Berdasarkan Gambar 2 menunjukkan sebagian besar responden memiliki sikap baik $(51 \%)$ dan sebagian kecil memiliki sikap kurang $(17,7 \%)$.

\section{c. Sarana Prasarana}

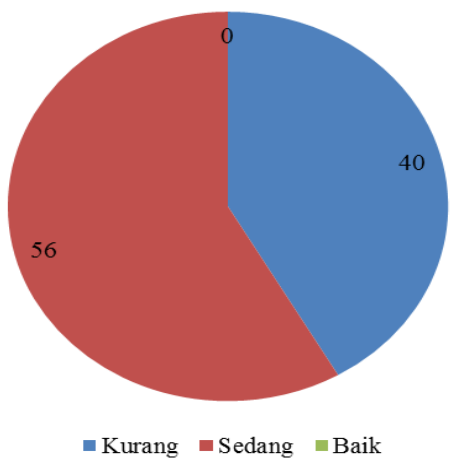

Gambar 3. Distribusi Frekuensi Responden Berdasarkan Sarana Prasarana di Puskesmas

Karanganyar II Demak $2018(\mathrm{n}=96)$

Berdasarkan Gambar 3 menunjukkan sarana prasarana adalah sedang $(58,3 \%)$ dan sebagian kecil menyatakan sarana prasarana kurang $(41,7 \%)$.

d. Sikap Petugas Kesehatan

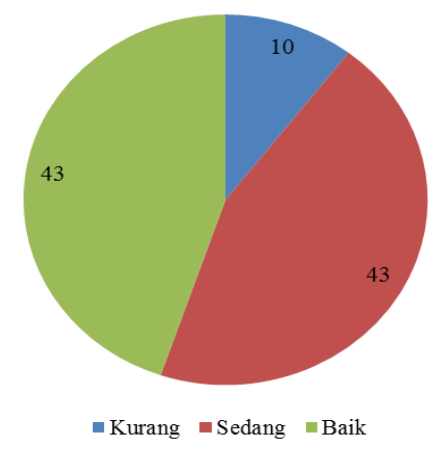

Gambar 4. Distribusi Frekuensi Responden

Berdasarkan Sikap Petugas Kesehatan di Puskesmas Karanganyar II Demak $2018(\mathrm{n}=96)$

Berdasarkan Gambar 4 menunjukkan sebagian besar responden menyatakan sikap petugas kesehatan adalah sedang dan baik $(44,8 \%)$ dan sebagian kecil menyatakan kurang $(10,4 \%)$.

\section{e. Pemanfaatan Poliklinik gigi}

Berdasarkan jumlah kunjungan poliklinik gigi di Puskesmas karanganyar II pada bulan Pebuari dan Maret, yaitu jumlah kunjungan poliklinik gigi adalah kurang pada bulan Februari dengan jumlah kunjungan 78 orang pasien dan jumlah kunjungan poliklinik gigi baik pada bulan Maret dengan jumlah kunjungan 151 orang pasien.

\section{Hasil Analisa Bivariat}

a. Pengaruh tingkat pengetahuan dengan pemanfaatan poliklinik gigi di Puskesmas Karanganyar II Demak 2018

Tabel 1. Distribusi Frekuensi Responden Berdasarkan Pengaruh Tingkat Pengetahuan dengan Pemanfaatan Poliklinik gigi di Puskesmas Karanganyar II Demak

\begin{tabular}{|c|c|c|c|c|c|c|c|}
\hline \multirow{2}{*}{$\begin{array}{r}\text { Pemanfaatan } \\
\text { poliklinik gigi } \\
\text { Tingkat pengetahuan }\end{array}$} & \multicolumn{2}{|c|}{ Kurang } & \multicolumn{2}{|c|}{ Baik } & \multicolumn{2}{|c|}{ Total } & \multirow[t]{2}{*}{$p$ value } \\
\hline & $\mathrm{n}$ & $\%$ & $\mathrm{n}$ & $\%$ & $\mathrm{n}$ & $\%$ & \\
\hline Kurang & 0 & 0,0 & 0 & 0,0 & 0 & 0,0 & \multirow{4}{*}{0,000} \\
\hline Sedang & 53 & 89,8 & 6 & 10,2 & 59 & 100,0 & \\
\hline Baik & 18 & 48,6 & 19 & 51,4 & 37 & 100,0 & \\
\hline Total & 71 & 74,0 & 25 & 26,0 & 96 & 100,0 & \\
\hline
\end{tabular}

Hasil uji statistik Chi Square diperoleh $\mathrm{p}$ value $=0,000$. Perbandingkan yang didapat dan $\mathrm{p}$ value $<0,05$ sehingga dapat dinyatakan bahwa ada pengaruh tingkat pengetahuan dengan pemanfaatan poliklinik gigi di Puskesmas Karanganyar II Demak 2018. 
b. Pengaruh sikap responden dengan pemanfaatan poliklinik gigi di Puskesmas Karanganyar II Demak 2018

Tabel 2. Distribusi Frekuensi Responden Berdasarkan Pengaruh Sikap Responden dengan Pemanfaatan Poliklinik gigi di Puskesmas Karanganyar II Demak

\begin{tabular}{|c|c|c|c|c|c|c|c|}
\hline \multirow{2}{*}{$\begin{array}{l}\text { Pemanfaatan } \\
\text { poliklinik gigi } \\
\text { Sikap } \\
\text { responden }\end{array}$} & \multicolumn{2}{|c|}{ Kurang } & \multicolumn{2}{|c|}{ Baik } & \multicolumn{2}{|c|}{ Total } & \multirow[t]{2}{*}{$p$ value } \\
\hline & $\mathrm{n}$ & $\%$ & $\mathrm{n}$ & $\%$ & $\mathrm{n}$ & $\%$ & \\
\hline Kurang & 17 & 100,0 & 0 & 0,0 & 17 & 100,0 & \multirow{4}{*}{0,000} \\
\hline Sedang & 27 & 90,0 & 3 & 10,0 & 30 & 100,0 & \\
\hline Baik & 27 & 55,1 & 22 & 44,9 & 49 & 100,0 & \\
\hline Total & 71 & 69,8 & 29 & 30,2 & 96 & 100,0 & \\
\hline
\end{tabular}

Hasil uji statistik Chi Square diperoleh $\mathrm{p}$ value $<0,05$ sehingga dapat gigi di Puskesmas Karanganyar II Demak dinyatakan bahwa ada pengaruh sikap responden dengan pemanfaatan poliklinik

c. Pengaruh sarana prasarana dengan pemanfaatan poliklinik gigi di Puskesmas Karanganyar II Demak 2018

Tabel 3. Distribusi Frekuensi Responden Berdasarkan Pengaruh Sarana Prasarana dengan Pemanfaatan Poliklinik gigi di Puskesmas Karanganyar II Demak

\begin{tabular}{|c|c|c|c|c|c|c|c|}
\hline \multirow{2}{*}{$\begin{array}{r}\text { Pemanfaatan } \\
\text { poliklinik gigi } \\
\text { Sarana prasarana }\end{array}$} & \multicolumn{2}{|c|}{ Kurang } & \multicolumn{2}{|c|}{ Baik } & \multicolumn{2}{|c|}{ Total } & \multirow[t]{2}{*}{$p$ value } \\
\hline & $\mathrm{n}$ & $\%$ & $\mathrm{n}$ & $\%$ & $\mathrm{n}$ & $\%$ & \\
\hline Kurang & 33 & 82,5 & 7 & 17,5 & 40 & 100,0 & 0,107 \\
\hline Sedang & 38 & 67,9 & 18 & 32,1 & 56 & 100,0 & \\
\hline Baik & 0 & 0,0 & 0 & 0,0 & 0 & 0,0 & \\
\hline Total & 67 & 69,8 & 29 & 30,2 & 96 & 100,0 & \\
\hline
\end{tabular}

Hasil uji statistik Chi Square diperoleh $\mathrm{p}$ value $\geq 0,05$ sehingga dapat dinyatakan bahwa tidak ada pengaruh sarana prasarana dengan pemanfaatan poliklinik gigi di Puskesmas Karanganyar II Demak 2018.

d. Pengaruh sikap petugas kesehatan dengan pemanfaatan poliklinik gigi di Puskesmas Karanganyar II Demak 2018

Tabel 4. Distribusi Frekuensi Responden Berdasarkan Pengaruh Sikap Petugas Kesehatan dengan Pemanfaatan Poliklinik gigi di Puskesmas Karanganyar II Demak

\begin{tabular}{lrrrrrrrrr}
\hline \multicolumn{1}{r}{$\begin{array}{c}\text { Pemanfaatan } \\
\text { poliklinik gigi }\end{array}$} & \multicolumn{2}{c}{ Kurang } & \multicolumn{2}{c}{ Baik } & \multicolumn{2}{c}{ Total } & p value \\
\cline { 2 - 7 } $\begin{array}{l}\text { Sikap } \\
\text { petugas kesehatan }\end{array}$ & $\mathrm{n}$ & $\%$ & $\mathrm{n}$ & \multicolumn{1}{c}{$\%$} & $\mathrm{n}$ & $\%$ & \\
\hline Kurang & 10 & 100,0 & 0 & 0,0 & 10 & 100,0 & 0,000 \\
Sedang & 39 & 90,7 & 4 & 9,3 & 43 & 100,0 & \\
Baik & 18 & 41,9 & 28 & 58,1 & 43 & 100,0 & \\
\hline Total & 67 & 69,8 & 29 & 30,2 & 96 & 100,0 & \\
\hline
\end{tabular}

Hasil uji statistik Chi Square diperoleh $\mathrm{p}$ value $<0,05$ sehingga dapat dinyatakan bahwa ada pengaruh sikap petugas kesehatan dengan pemanfaatan poliklinik gigi di Puskesmas Karanganyar II Demak 2018. 
Hasil uji statistik Chi Square diperoleh $\mathrm{p}$ value $=0,000<0,05$ yang artinya ada pengaruh tingkat pengetahuan dengan pemanfaatan poliklinik gigi di Puskesmas Karanganyar II Demak 2018. Hasil ini menjelaskan semakin baik tingkat pengetahuan seseorang maka akan semakin baik untuk memanfaatkan pelayanan kesehatan poliklinik gigi di Puskesmas. Meskipun tidak dipungkiri dari hasil penelitian diperoleh adanya responden dengan tingkat pengetahuan baik namun kurang memanfaatkan poliklinik gigi Puskesmas, pun demikian sebaliknya. Hal ini dapat dijelaskan karena responden sudah terbiasa memanfaatkan fasilitas pelayanan kesehatan lain seperti ke dokter gigi, ahli gigi atau ke rumah sakit secara langsung untuk mendapatkan pelayanan kesehatan gigi serta kurangnya tersosialisasi poliklinik gigi di Puskesmas kepada masyarakat di wilayah kerja Puskesmas Karanganyar II Demak.

Menurut asumsi peneliti, adanya hubungan antara pengetahuan dengan pemanfaatan poliklinik gigi di Puskesmas karena responden yang memiliki tingkat pengetahuan kurang cenderung kurang memanfaatkan puskesmas dan sebaliknya responden yang memilki pengetahuan tinggi cendrung memanfaatkan Puskesmas untuk memperoleh pelayanan kesehatan. Ketidaktahuan responden tentang manfaat Puskesmas, apa saja yang dapat diperoleh dari pelayanan kesehatan di puskesmas dan program-program serta kegiatan-kegiatan apa saja yang dapat diperoleh oleh responden dalam memperoleh pelayanan kesehatan menyebabkan mereka tidak ingin memanfaatkan pelayanan kesehatan di Puskesmas. Bagi responden yang memilki pengetahuan tinggi dan tidak memanfaatkan puskesmas disebabkan lebih memilih pelayanan kesehatan bidan dan rumah sakit.

Hasil uji statistik Chi Square diperoleh $\mathrm{p}$ value $=0,000<\alpha=0,05$ artinya ada pengaruh sikap responden dengan pemanfaatan poliklinik gigi di Puskesmas Karanganyar II Demak 2018.Dapat disimpulkan semakin baik sikap responden semakin baik untuk memanfaatkan poliklinik gigi di Puskesmas. Namun masih adanya responden dengan sikap baik tetap kurang memanfaatkan poliklinik gigi di Puskesmas dan juga bagi responden dengan sikap kurang namun memanfaatkan poliklinik gigi di Puskesmas dengan baik. Dapat dijelaskan bahwa sikap adalah sebuah bentuk respon dan respon tersebut dapat berubah-ubah menurut faktor-faktor yang ada karena sikap dibentuk dari hasil individu dengan lingkunganya, seperti yang disampaikan Walgito 2001 (dalam Saam, 2013), menyebutkan pembentukan sikap seseorang adalah perpaduan faktor internal dengan faktor eksternal.Faktor internal seperti keadaan fisiologis, emosi, motif, minat, dan aspek-aspek psikologis lainnya.Faktor eksternal seperti pengalaman, norma-norma nilai, dan pendidikan.

Menurut asumsi peneliti, adanya hubungan antara sikap masyarakat dengan pemanfaatan puskesmas karena responden yang memilki sikap baik akan cendrung berprilaku untuk memanfaatkan poliklinik gigi Puskesmas karena didasari dengan pengetahuan mereka terhadap manfaat dari puskesmas. Sebaliknya bagi responden yang memilki sikap kurang terhadap pemanfaatan puskesmas maka mereka tidak akan termotivasi untuk memanfaatkan pelayanan kesehatan poliklinik gigi di Puskesmas karena tidak adanya penegetahuan mereka terhadap manfaat Puskesmas tersebut jadi mereka lebih cendrung tidak minat dan tidak yakin akan memperoleh pelayanan kesehatan yang baik untuk mereka.

Hasil uji statistik Chi Square diperoleh $\mathrm{p}$ value $=0,107 \geq \alpha=0,05$. Artinya tidak ada pengaruh sarana prasarana dengan pemanfaatan poliklinik gigi di Puskesmas Karanganyar II Demak 2018. Kesimpulan yang didapat adalah semakin kurang sarana prasarana poliklinik gigi Puskesmas maka semakin kurang responden untuk memanfaatkan poliklinik gigi Puskesmas. Adapun yang menyatakan sarana prasarana poliklinik gigi Puskesmas masih belum baik dan hal ini menyebabkan 
masyarakat di sekitar Puskesmas Karanganyar II Demak kurang memanfaatkan poliklinik gigi di Puskesmas dan yang menyatakan kurang namun masih memanfaatkan, dapat dijelaskan bahwa kemungkinan adanya yang masih memanfaatkan pelayanan poliklinik gigi Puskesmas Karanganyar II Demak karena hanya fasilitas inilah satu-satunya yang memberikan pelayanan gigi dengan cara terdekat dan tidak setiap hari responden harus memeriksakan gigi, selain itu faktor biaya yang berpengaruh untuk menentukan seseorang memilih poliklinik gigi Puskesmas untuk dimanfaatkan.

Peneliti berpendapat sarana prasarana untuk memberikan pelayanan kesehatan terutama di poliklinik gigi adalah hal perlu dan wajib karena dapat menunjang keberhasilan pelayanan yang berakibat pada kepuasan pasien yang akhirnya dapat memilih tetap memanfaatkan fasilitas pelayanan yang diberikan oleh penyedian layanan kesehatan tersebut.

Hasil uji statistik Chi Square diperoleh $\mathrm{p}$ value $=0,000<\alpha=0,05$ artinya ada pengaruh sikap petugas kesehatan dengan pemanfaatan poliklinik gigi di Puskesmas Karanganyar II Demak 2018. Kesimpulannya semakin baik sikap petugas kesehatan maka semakin baik responden untuk memanfaatkan poliklinik gigi di Puskesmas. Adapun responden yang masih kurang memanfaatkan poliklinik gigi di Puskesmas meskipun sikap petugas kesehatan sudah baik, lebih dikarenakan sikap sebagai respon dapat berubah-ubah dan tergantung dari faktor yang mempengaruhinya, meskipun sikap petugas kesehatan baik namun jika tidak ditunjang dengan fasilitas yang memadai atau mungkin memang sudah memiliki dokter gigi atau fasilitas kesehatan lain yang sudah dikenal maka memungkinkan responden memilih dokter gigi atau fasilitas kesehatan lain tersebut.

Peneliti berpendapat sikap petugas kesehatan yang sangat vital dalam pemberian pelayanan kesehatan, petugas kesehatan perlu menunjukkan sikap profesionalisme dengan berbagai kondisi yang ada dan tetap memberikan pelayanan yang tepat guna.

\section{KESIMPULAN}

1. Karakteristik pasien di Poliklinik gigi Puskesmas Karanganyar II Kabupaten Demak yaitu sebagian besar responden berumur 20-29 tahun dan 30-39 tahun sebanyak 39 orang $(40,6 \%)$, berjenis kelamin perempuan sebanyak 53 orang $(55,2 \%)$, dengan pendidikan sebagian besar responden berpendidikan SMA sebanyak 48 orang $(50 \%)$ dan berdasarkan pekerjaan sebagian besar responden bekerja sebagai buruh sebanyak 56 $(58,3 \%)$.

2. Faktor-faktor yang mempengaruhi rendahnya pemanfaatan poliklinik gigi di Puskesmas Karanganyar II Demak, adalah:

a. Tingkat pengetahuan dengan nilai ( $p$ value $=0,000$ )

b. Sikap masyarakat ( $\mathrm{p}$ value $=0,000)$

c. Sikap petugas kesehatan dengan (p value $=0,000)$

3. Faktor-faktor yang tidak mempengaruhi rendahnya pemanfaatan poliklinik gigi di Puskesmas Karanganyar II Demak, adalah sarana dan prasarana poliklinik gigi di Puskesmas Karanganyar II Demak (pvalue $=0,107)$.

\section{DAFTAR PUSTAKA}

Anorital, Mulyati S, Andayasari L. 2011. Gambaran Ketersediaan Tenaga dan Upaya Pelayanan Kesehatan Gigi di Puskesmas.

Budiharto.2010. Ilmu Perilaku Kesehatan dan pendidikan Kesehatan Gigi. Buku Kedokteran EGC. Jakarta.

Dwianti, I. 2010. Gambaran Faktor-faktor yang Mempengaruhi Pemanfaatan Puskesmas Liu Kecamatan 
Sabbangparu Kabupaten Wajo. Jurusan Keperawatan Fakultas Ilmu Kesehatan Universitas Islam Negeri Alauddin Makasar.

Herlambang S. 2016. Manajemen Pelayanan Kesehatan Rumah Sakit, Gosyen Publising. Yogyakarta.

Hidayat R, Tandiari A. 2016. Kesehatan Gigi dan Mulut Apa Yang Sebaiknya Anda Tahu?. Andi.Yogyakarta.

Imron M, dan Munif A, 2012. Metodologi Penelitian Bidang Kesehatan. Sagung Seto.

Kiswaluyo. 2011. Pelayanan Kesehatan Gigi di Puskesmas.

Kementrian Kesehatan RI Tahun 2012.Pedoman Paket Dasar Pelayanan Kesehatan Gigi dan Mulut di Puskesmas.

.www.dep.kes.go.id/profil

kesehatan.pdf-Diakses Desember 2017.

Kementrian Kesehatan RI Tahun 2013. Laporan Nasional Riset Kesehatan Dasar (RISKESDES2013). www.dep.kes.go.id/riskesdes2013pdf-Diakses Desember 2017.

Kementrian Kesehatan RI Tahun 2012. Tentang Sarana Pusat Kesehatan Masyarakat.

www.dep.kes.go.id/profil kesehatan.pdf-Diakses Desember 2017.

Katrin. 2010. Pendidikan dan Perilaku Kesehatan. Jakarta.

Muninjaya, G. 2012.Manajemen Mutu Pelayanan Kesehatan, Buku Kedokteran EGC. Jakarta.
Notoatmodjo, S. 2012. Promosi Kesehatan dan Perilaku Kesehatan. Rineka Cipta. Jakarta.

Nugrahaningsih, W.2016. Hubungan Sikap Perawat dengan Kepuasan Pasien dalam Pelayanan Keperawatan di Bangsal Paviliun RSUD Salatiga.

Peraturan Pemerintah Republik Indonesia Nomor 47 Tahun 2016 Tentang Fasilitas Pelayanan Kesehatan.www.hukumonline.compdf-Diakses Desember 2017.

Permenkes RI No.75 Tahun 2014. Tentang Pusat Kesehatan

Masyarakat.www.indonesianpublichealth.com/download-pdfDiakses Desember 2017.

Satrianegara F. 2014. Organisasi dan Manajemen Pelayanan Kesehatan. Salemba Medika. Jakarta.

Swajarna I. K., 2015. Metodologi Penelitian Kesehatan. Andi.Yogyakarta.

Utomo, T. D. 2013. Hubungan antara Keteersediaan Sarana dan Prasarana Usaha Kesehatan Sekolah dengn Perilaku Hidup Sehat Siswa Kleas VI SDN Mungkung Kecamatan Kalijajar Kabupaten Wonosobo. 